Khanyile MLOTSHWA

University of KwaZulu-Natal

Pietermaritzburg, South Africa

khanyilemlotshwa@gmail.com

\title{
MATABELELAND AND THE RULERS' POLITICAL SINS: DEFINING SUBVERSIVE ART IN ZIMBABWE
}

Recommended Citation: Mlotshwa, Khanyile. "Matabeleland and the Rulers' Political Sins: Defining Subversive Art in Zimbabwe." Metacritic Journal for Comparative Studies and Theory 5.1 (2019): https://doi.org/10.24193/mjcst.2019.7.04

Abstract: Zimbabwe has a culture of protest art in theatre with a long history that goes back to the country's independence from British colonial rule in 1980. However, a culture of subversive art in other artistic genres, such as visual arts, has emerged in recent years. This paper focuses on the fate of two art events, a theatre play and a visual arts exhibition, both closed down and banned in Bulawayo, the country's second largest city, which is also regarded as the country's cultural capital. In 2007, The Good President, a play by the Zimbabwean playwright and theatre director and producer Cont Mhlanga, was stopped from running in the city and banned from stage in the country (Mwando 1). This is despite the fact that the play had had an unhindered run in Harare, the capital city, where it had premiered. In 2010, visual artist and painter, Owen Maseko's exhibition focusing on the 1983 - 1987 Gukurahundi genocide was shut down (Sokwanele 1, Ncube and Siziba 233, Mpofu 60). The closing down of his exhibition and the closing off of that section of the gallery that housed his exhibition symbolised that Matabeleland, as a region, is still a crime site. Located within anti-colonial - postcolonial and decolonial theoretical lenses, in this paper, I read the two events around the aborted staging of the two arts events to consider definitions and self-definitions of subversive art (Wiseman and Yuedi, Sulieman, Cohen 69) in Zimbabwe. In that the Matabeleland region has always been characterised as the hotbed of opposition politics, I ask the question of why art produced and performed in Matabeleland is viewed with suspicion by the country's rulers. 
Keywords: theatre, visual arts, postcolonial studies, decolonial studies, subversive art

In his award-winning play, Nansi Le Ndoda (Here Is the Man) produced and performed in 1985, the renowned playwright Cont Mhlanga tells a story of corruption, greed and hyperinflation. The play also tackles "such negative tendencies as (...) nepotism, bribery and sexual harassment at places of work and regionalism in independent Zimbabwe" (Chifunyise 278). At the time when it was produced it really spoke to the conscience of the nation and won 5 awards at the National Theatre Organisation (NTO) annual awards in 1985 (Dube 44). This is the play that brought Mhlanga, and his Amakhosi Theatre brigade, into the imagination of the Zimbabwean nation and earned him international recognition. The play's prophetic and poetic power caught the hearts and minds of Zimbabweans who have come to associate Mhlanga with a robust brand of protest theatre. For a long time, Mhlanga has been regarded as not only an enemy of the state by the ruling elite, but also a Ndebele nationalist.

Understanding the history of Amakhosi Theatre, as a brigade of artistic youth out of the township, and Mhlanga, as belonging to the working class, and not just close to, but living the struggle of the ordinary people, is important. Amakhosi Theatre started as Dragons Karate Club until Cont Mhlanga attended the theatre workshops organised by the National Theatre Organisation (NTO) in 1980 at Stanley Hall in Makokoba, Bulawayo's oldest township. The group then changed from Dragons Karate Club to Amakhosi Theatre in 1981 and by 1990 had appeared on stage more than 295 times and was made up of about 110 young people (Dube 44). According to Dube, “Amakhosi's programme has been to take theatre to ordinary people" (Dube 44). From the vantage point of his location in the township environment, Mhlanga could observe the suffering that had already hit working class families, something that the middle class might not have seen. In a sense, Mhlanga and his group could already understand what suffering as a result of leadership failure or the neglect of the state means.

Part of the Amakhosi Theatre's history narrated above shows that Zimbabwe's subversive or protest art theatre can be traced back to its independence moment in April 1980, a moment believed to have marked the beginning of its postcolonial trajectory, and meant to be a decolonial moment. This is also the moment of the 
beginning of the mistrust between the ruling elite in Harare and the Matabeleland region, which has been characterised as the dissident region. Between 1982 and 1987, a government operation in the Southern parts of Zimbabwe led to the death of over 20000 civilians (Catholic Commission for Justice and Peace and the Legal Resource Foundation). This operation has been declared a genocide by the Genocide Watch. In a large sense, Mhlanga and Amakhosi Theatre's emergence as protest artists, speaking truth to power, is tied to their location in Matabeleland, a region that has always felt excluded from government (development) problems.

Although the culture of protest or subversive art has a long history in theatre, this culture in other artistic genres, such as visual arts, has emerged in recent years. This paper focuses on the fate of two art events, a theatre play and a visual arts exhibition, both closed down and banned in Bulawayo, the country's second largest city, which is also regarded as the country's cultural capital. In 2007, Zimbabwean playwright and theatre director and producer Cont Mhlanga's play, The Good President, was stopped from running in the city and banned from stage in the country (Mwando1). This is despite the fact that the play had had an unhindered run in Harare, the capital city, where it had premiered. In 2010, visual artist and painter Owen Maseko's exhibition focusing on the $1983-1987$ Gukurahundi genocide was shut down (Sokwanele 1, Ncube and Siziba 233, Mpofu 60). Nonetheless, Maseko had shown strength in challenging the government over the telling of the Gukurahundi story. The closing down of his exhibition and the closing off of that section of the gallery that housed Maseko's exhibition and the outlawing of any performance of Cont Mhlanga's play, in a larger sense, symbolised that Matabeleland, as a region, is some kind of a crime site.

In this paper, I read the two events around the aborted staging of the two arts events - the theatre play and the exhibition - to consider definitions and selfdefinitions of subversive art (Wiseman and Yuedi, Sulieman, Cohen 69) in Zimbabwe. In that arts events in other parts of the country rarely have problems from the country's rulers, I consider theoretical issues in how the definition of subversive art in Zimbabwe may be articulated to the country's political dynamics. In that the Matabeleland region has always been characterised as the hotbed of opposition politics, I ask the question of why art produced and performed in Matabeleland is viewed with suspicion by the country's rulers. 


\section{Postcoloniality, decoloniality and the state in Zimbabwe}

This paper combines postcolonial and decolonial insights to construct an anticolonial theoretical framework. Although postcolonialism and decoloniality can be regarded as distinct theories, the traditions that are associated with each are "long-standing and diverse" (Bhambra 115). In this section, I will briefly describe both postcolonial and decolonial theories, touching on their differences and their similarities. I will then discuss how and why I combine the theories that at face value look different and opposed.

Postcolonialism is associated with Southern Asia and the Middle East, seen as emerging in the work of Edward Said, Gayatri Spivak and Homi Bhabha; and decolonial thought is associated with the works of the modernity/coloniality group clustered in Latin America including Anibal Quijanos, Maria Lugones and Walter Mignolo, among others (Bhambra 115; Asher 512). Most of the work in postcolonial studies, although it touches on socio-economic issues, is firmly focused on the cultural; while decolonial studies stems from work around development and is linked to world-systems analysis (Bhambra 115). One similarity is that both traditions emerge within Western metropoles. Postcolonialism is a result of the work of diasporic scholars from South Asia and the Middle East and takes those locations as its reference (Bhambra 115). The decolonial perspective emerges from diasporic scholars from South America and refers back to those locations. The difference between the two is that decolonial theory addresses a much longer time frame. Bhambra notes that "whereas postcolonialism refers mainly to the nineteenth and twentieth centuries, decoloniality starts with the earlier European incursions upon the lands that came to be known as the Americas from the fifteenth century onwards" (Bhambra 115).

However, despite these differences, there are a number of similarities as well for the theoretical traditions. Both theoretical traditions seek to challenge "the insularity of historical narratives and historiographical traditions emanating from Europe" (Bhambra 115). These bodies of anticolonial theory have each trenchantly demonstrated the limits of universalising European modernity that arose out of slavery, colonialism and the empire. Bhambra notes that postcolonialism and decoloniality, in their various traditions, offer a "radical potential in unsettling and reconstituting standard processes of knowledge production" (Bhambra 115). She regrets that, however, "there has been little work, thus far, bringing together the 
various trajectories of these fields" (Bhambra 115). This paper contributes to covering this gap that, of late, has been characterised by the "eclipsing of postcolonialism ... increasingly ... viewed as passé” and a setting up of decoloniality "as always already better in time" (Ramamurthy and Tambe 504).

In this paper, I use the concept of the "colonial presence," taken from Gregory's work on Palestine and the Middle East and referring to "the performative force of colonial modernity," to bring together postcolonialism and decoloniality as anticolonial theories (Gregory 4). In the 'colonial present,' the concept of postcolonialism is evoked as that time when the focus shifts from "present futures to present pasts" (Huyssen 57). Gregory notes that post colonialism's “commitment to a future free of colonial power and disposition is sustained in part by a critique of the continuities between the colonial past and the colonial present" (Gregory 7). Stuart Hall defines the postcolonial as the conjectural moment "in which both the crisis of the uncompleted struggle for 'decolonisation' and the crisis of the 'post-independence' state are deeply inscribed” (Hall 224). Gregory further points out that, "while they may be displaced, distorted, and (most often) denied, the capacities that inhere within the colonial past are routinely reaffirmed and reactivated in the colonial present" (Gregory 7). The postcolonial is best thought of as a continuation of the colonial, with just the change of guard in terms of state apparatus. The Zimbabwean black government took over the state apparatus in April 1980 but kept Rhodesian laws like the Law and Order Maintenance Act (LOMA) intact, only modifying it into the still draconian Order Security Act (POSA) after 2000.

While emphasising that coloniality is different from colonialism, MaldonaldoTorres defines it as "long standing patterns of power that emerged as result of colonialism, but that define culture, labour, intersubjective relations, and knowledge production well beyond the strict limits of colonial administrations" (MaldonaldoTorres 243). Ndlovu-Gatsheni refers to coloniality as "a leitmotif of global imperial designs (...) the invisible vampirism of technologies of imperialism and colonial matrices of power that continue to exist in the minds, lives, languages, dreams, imaginations, and epistemologies of modern subjects in Africa and the entire global South" (Ndlovu-Gatsheni 11).

Although decolonial theorists argue, and insist, that decoloniality is not postcolonialism, this essay locates its argument in the point of convergence between 
the two as anti-colonial theoretical postures (Bhambra 115, Asher 512). The essay brings together postcolonial and decolonial theories in thinking through the intersections between protests or subversive art and ethnicised politics in a postcolonial Zimbabwe. What other scholars like Mhlanga refer to as the problem of the North is seen as enduring coloniality in the postcolonial moment (Mhlanga 105). The two theoretical traditions - postcolonial and decolonial - are combined because the way Hall thinks about the endurance of colonialism in the postcolonial moment is not different from the emphasis that Maldonaldo-Torres and Ndlovu-Gatsheni place on coloniality as born out of colonialism and modernity. Ideas of the state and the nation in Zimbabwe are trapped in coloniality. The state continues with the draconian inclinations of its predecessor, Rhodesia, and the nation is still imagined in the ethnicised fashion propagated and nurtured by the settler Rhodesian regimes.

\section{Defining subversive or protest art}

Subversive or protest art is when art's inherent political nature emerges and collides with invested powers in society. The argument here is that, as communication, all art is political. To fully argue this point out, it is important to consider a definition of politics. Mouffe offers a more useful conceptualisation of politics as she distinguishes between 'politics' and 'the political' (Mouffe, On the political, 9). She argues that "by 'the political' I mean the dimension of antagonism which I take to be constitutive of human societies, while by 'politics' I mean the set of practices and institutions through which an order is created, organising human co-existence in the context of conflictuality provided by the political" (Mouffe, On the political, 9). Art is both political and politics. It is political because it always addresses conflict or that point in human society where something is wrong. It is politics because in a sense it is both a practice and an institution that aspire for a certain organisation of society in light of the "ineradicable character of power and antagonism" in society (Mouffe, The return of the political, vii). Subversive or protest art, then, is art that makes its politics clear. It is art that, Jonson notes, creates cultural factors that can agitate citizens and bring a shift in their political values, and may lead to an outburst of protest (Jonson 1).

Writing on developments in Russia from December 2011 to May 2012, Jonson argues that "culture - in particular the visual arts - played a crucial role" (Jonson 1). He points out that "developments in other places and at other times have shown that value shifts usually precede great upheavals and that these shifts are often visible in 
the cultural sphere before they are articulated in political terms in wider society" (Jonson 2). This could explain the reasons why the government clamped down on the two performances. They would have been convinced that, as artistic events, it was likely that they would be key in the "slow transformation of societal values" leading to changes in politics (Bleiker 181). This is because, as Jonson points out "the development of art was not only confluent with evolving demands in the political sphere, but it also visualized what was going on in people's minds before it had been formulated in political terms" (Jonson 3). Protest art is when art challenges "official truths and perceptions" (Jonson 3). Reeds makes a link between subversive art and social movements arguing that there are "relations between culture and social change" (Reeds xiii). He defines social movements as "the unauthorized, unofficial, anti-institutional, collective action of ordinary citizens trying to change their world" and argues that this has shaped politics, culture, and political culture (Reeds xiv).

\section{The Matabeleland question as a "Northern problem"}

Mhlanga has argued that most African countries have a "Northern problem" where the nation as an agonistic arrangement with a majority ethnic group dominating a minority ethnic group to the extent of subalternising it (Mhlanga 210). The Northern problem refers to "the existence of a disgruntled group claiming a particular history and a particular identity that is different from the dominant ethnic groups that have tended to benefit from the state" (Mhlanga 210). This is as a part of the colonial heritage (Caplan 343). According to Mhlanga, this has nothing to do with the geographic location of this disgruntled group in the country, whether in the North or South of the country, but it has something to do with the idea that the Northern problem is a colonial inheritance or is rooted in the colonial moment. Matabeleland, as a Southern region of Zimbabwe, sees itself as dominated by the central government located in Harare. In this arrangement, Mashonaland has been viewed as the "land of the rulers" while Matabeleland has been viewed as "the land of the ruled" (Mhlanga207). There are ethnic animosity issues involved. Ndlovu-Gatsheni has characterised Zimbabwean nationalism as bi-modal where Shona nationalism is contested by Ndebele nationalism (Ndlovu-Gatsheni, Subjectivity 526). In material terms, Matabeleland, as a geographic space, is a block of provinces that include Matabeleland North, Matabeleland South and the metropolitan province of Bulawayo. This block of provinces is mostly combined with the Midlands to create an 
ethnicised Matabeleland/ Midlands construct that focuses mostly on the areas where people regarded as Ndebele live (Mlotshwa88). The Matabeleland question arises out of the Southern region's feelings of being marginalised by its Northern counterparts. The Matabeleland Question is a long discourse predicated on issues of ethnicity and marginalisation.

Muzondidya and Ndlovu-Gatsheni note that, although it is publicly denied, ethnicity continues "to shape and influence" Zimbabwe's economic, social, and political life and this has been the case since the country's independence from British colonial rule in April 1980 (Muzondidya and Ndlovu-Gatsheni 275). This is based on what the two writers describe as "the political economy of ethnicity inherited from the colonial past" (Muzondidya and Ndlovu-Gatsheni 275). They argue that although Gukurahundi marks the only time in Zimbabwean history when ethnic animosity combined with politics leading to the genocide, "there is serious ethnic polarisation in the country and ethnicity remains one of the challenges to the survival of both the state and the country" (Muzondidya and Ndlovu-Gatsheni 275). The nationalist politics of Zimbabwe is such that it puts emphasis on the Machel dictum "for the nation to live, the tribe must die" and therefore practises what can be referred to as the hypocritical politics of ignoring ethnicity in public yet embracing it at night. In public, this discussion on ethnic and cultural pluralism and diversity has been caricatured as "retrogressive" (Mhlanga207). Muzondidya and Ndlovu-Gatsheni note that the Zimbabwean government at independence ignored the messy task of engaging ethnicity and "addressing historical and contemporary factors that continued to make ethnicity an important issue in people's lives" (Muzondidya and Ndlovu-Gatsheni 276). There are two reasons that made this an important historical task. The first one is that, as history would attest, when the Gukurahundi genocide broke out in 1982, it quickly took an ethnic war form. The second reason is that, as a colonial inheritance, state institutions have been calibrated in such a way that they "enacted and reproduced ethnicity" (Muzondidya and Ndlovu-Gatsheni 276).

The Zimbabwean civil service has been organised in an ethnicised way from the colonial period. For example, in the police service, the Rhodesian government ensured that police officers deployed in Matabeleland were mostly from Mashonaland (and therefore Shona) while those deployed in Mashonaland provinces were mainly from Matabeleland (and therefore Ndebele). Even in the media, there was emphasis that journalists or broadcasters at the Rhodesian Broadcasting 
Corporation spoke both Ndebele and Shona, in addition to English. The Zimbabwean government ignored ethnicity and, as Muzondidya and Ndlovu-Gatsheni note, "such neglected processes, structures and institutions included unequal development of the provinces and the marginalisation of particular ethnic groups in politics, economy and society" (Muzondidya and Ndlovu-Gatsheni 276). The said marginalisation is what has been described as the Matabeleland Question within Zimbabwean nationalism.

Mhlanga sees the Zimbabwe state's politics as "tribalised" and like a "bad birth mark continues to haunt the national project" (Mhlanga 207). To Mhlanga the tribalisation of the state has led to the unequal distribution of national resources (Mhlanga 207). This very fact that resource distribution in Zimbabwe often takes ethnicity contour lines is what gives rise to the Matabeleland Question. The Matabeleland Question here is seen as the political demand to have national resources distributed fairly and equally. Mhlanga argues that, rather than labelling the ethnic question as 'bad tribalism' it is important to engage it "as political currency which should be understood and explained" (Mhlanga 209). Here he draws on Commaroff who notes that ethnicity is not simply an ontological feature of people but a result of specific historical moments (Commaroff 70).

To illustrate the ethnicised marginalisation of Matabeleland, Mhlanga points to the fact that in 1987 when the government of Zimbabwe decided to electrify the railway line between Harare, the capital city, and Bulawayo, the second largest city in the country, it only did so between Harare and Gweru. This is despite the fact that the headquarters of the National Railway of Zimbabwe (NRZ) are in Bulawayo and the biggest power generation station is Hwange Power Station, located in Matabeleland North, which generates 920 Megawatts (Mhlanga 210-218). Mhlanga further points to the centralisation of everything in Harare which has created bottlenecks in the operations of the busiest borders in the country - Beit Bridge, Kazungula and Plumtree - which are located between Zimbabwe and South Africa, Zambia and Botswana, countries with high active economies compared to Zimbabwe. Industries have been relocating from Bulawayo to Harare, leaving the former industrial capital of the SADC region a ghost town. As recent as 2017, the cement manufacturing giants Pretoria Portland Cement (PPC) closed their factories in Bulawayo and relocated to Harare despite the fact that they mine their cement a few kilometres from Bulawayo in Matabeleland South. Mhlanga blames the relocation of 
these industries on the government's refusal to fund the Matabeleland Zambezi water Project, which is seen as providing long term solutions to Bulawayo's water problems.

Ncube and Siziba discuss the Matabeleland Question in the context of cultural production arguing that "the deep-rooted Shona hegemony across all fields of cultural practice in Zimbabwe has compelled some Ndebele arts performers to use Shona language in order to appeal culturally to a Shona audience" (Ncube and Siziba 825). They see Zimbabwe's 'Shonacentric habitus' functioning as "an unspoken law" that has the effect of devaluing non-Shona towns and cities and in the process generating "self-censorship and self-subordination" among non-Shona artists, in general, and Ndebele artists, in particular (Ncube and Siziba 825). In a sense, non-Shona and Ndebele artists are caught up in a hegemonic cultural field in Zimbabwe, where they have to give up or compromise on their cultures to identify with the dominant Shona culture if they are to have successful arts careers. Ncube and Siziba use the case of popular Matabeleland performers, Sandra Ndebele and Afrika Revenge who, not only had to relocate to Harare from Bulawayo, but had to adopt Shona in their work (Ncube and Siziba 830). Ncube and Siziba locate this arrangement - where Ndebele speakers have to perform in Shona - in the "wider socio-cultural and political context" of Zimbabwe to argue that "these modes of marginalisation, exclusion and silencing are manifest in the field of the arts" (Ncube and Siziba 831). This is an important point to bear in mind as we turn to discuss how art/culture becomes imbricated with politics and socio-economic structures in the case of Cont Mhlanga's play, The Good President, and Owen Maseko's ill-fated exhibition.

Gukurahundi, which was the theme of Maseko's exhibition, refers to the killing of about 20 ooo people in Matabeleland between 1983 and 1987, and is seen as central to the marginalisation of Matabeleland and the Matabeleland Question. The most radical activists in Matabeleland have argued that the 'killing' of the people of the region did not stop with the signing of the Unity Accord between Zanu PF and PF-Zapu parties in December 1987, but continues to date. They characterise this as soft killing seen in the denial of economic opportunities for Matabeleland citizens in Zimbabwe. In the next section, we briefly describe and discuss Gukurahundi so as to locate it within the Matabeleland Question. 


\section{A brief on the Gukurahundi genocide of 1983-1987}

After Zimbabwe's independence in April 1980, there soon emerged animosity within the unity government that was in charge of the country's affairs. In 1982, the Zanu Pf part of the government, which had power and dominated the government, claimed to have unearthed arms of war hidden by the Zapu party. Zanu PF through the Prime Minister Robert Mugabe, security minister Enos Nkala claimed these arms of war were meant to overthrow the government of Robert Mugabe. The Gukurahundi, therefore, refers to a series of massacres of Ndebele civilians in the southern part of the country. This was mostly confined to the Matabeleland North, Matabeleland South and parts of Midlands provinces. The most intense of the massacres were within the Ndebele speaking regions. The government specially trained the Fifth Brigade to carry out the murders and forced disappearances. It was between 1983 and 1987. The word Gukurahundi comes from a Shona word meaning "the early rain which washes away the chaff before the spring rains". There are contestations over the number of people killed, but the CCJP and LRF, and the International Association of Genocide Scholars puts the figure at over 20 ooo people killed.

\section{Matabeleland and the geography of protest art in Zimbabwe}

Two arts events, one that had Gukurahundi, the genocide, as part of its themes, and another that solely focused on the genocide, appeared within a space of three years between each other. In 2007, Zimbabwean playwright and theatre director and producer Cont Mhlanga's play, The Good President, was stopped from running in the city and banned from stage in the country (Mwando 1). This is despite the fact that the play had had an unhindered run in Harare, the capital city, where it had premiered. In 2010, visual artist and painter Owen Maseko's exhibition focusing on the 1983 - 1987 Gukurahundi genocide was shut down. The government's response of shutting down these two arts events highlighted two issues. First, it pointed to the power of the arts to scare the government. Second, it highlighted that Matabeleland was still a festering crime scene as far as the genocide is concerned. The fact that Mhlanga's play had a free run in Harare, only to be closed down when it went to Bulawayo, buttresses the second point. We now turn to discuss the case of Cont Mhlanga's The Good President. 


\section{Cont Mhlanga and the Good President}

Cont Mhlanga has, over the years, built a reputation as a critical theatre artist with his productions speaking to the conscience of the government and all the leaders. Journalist Smith notes that "Mhlanga has been a constant thorn in the side of President Robert Mugabe” (Smith 1). Talking about the saga around his last play, The Good President, Smith notes that "after the curtain call at one of his earliest plays, officials from the state took to the stage to denounce him and his work. How dare he criticise the black heroes of the liberation?" Mhlanga founded Amakhosi Theatre in 1982 at the time Zimbabwe turned independent. Amakhosi started off as a karate club turning semi-professional in 1988. At that time, Amakhosi had an arts training centre, the Amakhosi Performing Arts Workshop (APAW), and also produced theatre plays - written and directed by Mhlanga - and toured around the world. In 1988, Mhlanga's play, Workshop Negative, focusing on corruption among political leaders became a hit in the country. However, the play was banned from being performed abroad. The satirical play depicts the relationship between two adversaries in Zimbabwe's seven-year war for independence - one white and one black - who are both exploited by their black employer, who professes to be communist but is a blatant capitalist. This mocked the country's leadership who, while claiming to be Marxists socialists, were some of the richest people in the country owning businesses and, together with international capital, controlled a large chunk of the economy. Mhlanga described it as focusing on "people who preach socialism and practice capitalism" (Bartlett 1). The then minister of youth, sport and culture, David Karimanzira, felt that the play denigrated socialism and portrayed the country's political leaders as corrupt, charging that it "does not depict a true reflection of the political developments in Zimbabwe" (Bartlett 1).

In 1995, Mhlanga and Amakhosi Theatre established the Township Square Cultural Centre at the edge of Makokoba, Bulawayo's oldest township. In his career, Mhlanga has written over 20 plays. His work has always been informed and inspired by the challenges that people face in their day to day lives as a result of bad leadership. As a result, Mhlanga was arrested and briefly detained in May 2006 accused of being anti-government in his work. Former president Robert Mugabe's government felt that Mhlanga's work was meant to incite the masses against them.

The play The Good President, which was presented as a fictional story of an African dictator who has ruled his country for a long time, was banned by the 
government when it premiered in Bulawayo, the country's largest city. The play The Good President also featured a myriad of problems around the president that included criticism of official corruption, executive-sanctioned terror and presidential misconduct. The satirical play had a free run in Harare, the capital city, drawing thousands of people to see and hear the criticism of the ruling elite. However, in the following month, in June, the play was banned from premiering in Bulawayo. After the banning of the play, the deputy Information Minister, Bright Matonga, said protest and political theatre is the "work of political activists masquerading as artists" (in Mwando 1). The play was set to open at the Bulawayo Arts Theatre, a former colonial government built theatre venue, when police stormed the venue minutes before it was staged. Their reason for stopping the play was that it is political. Meanwhile, as the government's response was to ban the play The Good President won an Art Venture Freedom to Create award, shrugging off challenge from nearly 1,00o entrants from 86 countries.

In his interview with Smith in 2009, Mhlanga expressed his faith in theatre as a protest tool. Comparing it to journalism and other forms of expression, Mhlanga emphasises that

Art is most important of all. With the news you only get one version of events. Art is the best way of telling the rest of the world what is happening. You can't get more political than Shakespeare, who wrote about kings. But even when you tell a joke in the street, that is political. When there is so much going on, everything is political (Mhlanga in Smith 1).

Mhlanga's lifelong career in theatre seems to have been committed to speaking truth to power. Chikonzo notes that, between 1999 and 2008, Zimbabwean theatre artists responded with a number of protest plays to the political and economic crisis gripping the country at that time. He argues that the rise of protest theatre was to "compensate for a media monopoly by the state, to promote active citizen engagement in politics, and to promote political change" (Chikonzo 218). Importantly, Chikonzi distinguishes between this theatre and the reconciliatory protest theatre, "a brand of protest theatre that emerged after the crisis in Zimbabwe, after the formation of a Government of National Unity" (Chikonzo 218). Even though The Good President seems to belong to the pre-2008 brand of theatre, since it was produced in 2007, by touching on Gukurahundi and other forms of political violence 
it shares some similarities with the reconciliatory protest theatre. The reconciliatory protest theatre plays were "concerned with issues of national healing and reconciliation which dominated the post-crisis situation in Zimbabwe" (Chikonzo 218). Like the reconciliatory protest theatre, The Good President agreed with the state that "the nation ought to be healed and that reconciliation was needed" but the bone of contention was on how to go about implementing this reconciliation.

\section{Owen Maseko and the ill-fated exhibition}

Zimbabwean visual artists Owen Maseko has said his work, especially his banned exhibition of the 1980's genocide, is aimed at helping the country heal itself (Smith 1). In March 2010, Maseko was arrested less than 24 hours after his exhibition, "Sibathontisele" ("Let's Drip on Them") opened at the Bulawayo National Art Gallery. He spent four nights in police cells. The theme is an allusion to blood spilt during the genocide and, more importantly, to the form of torture using burning plastic that was institutionalised during the killing of over 20,000 Ndebele civilians between 1983 - 1987. Maseko was charged, under the Public Order and Security Act, with "undermining the authority" of the president, and "causing offence to persons of a particular race or religion". The charges carried a possible twenty-year prison sentence. However, Maseko insists that he put up his exhibition because he felt there is a need to confront the past in order to help the country heal itself, after decades of brutal rule by the Zanu PF government. Maseko, like Mhlanga sees the brutality that comes after 1987 as linked to the Gukurahundi brutality, as existing in the same discourse of brutal leadership. Maseko notes that "there are mass graves in our country. If people are to move on, they need to rebury their brothers, sisters and mothers in peace." What Maseko is raising is a commonly accepted idea in justice studies, especially transitional justice. In arresting and banning Maseko and Mhlanga's work, it would seem like the government is in denial of this history. By banning and arresting artists, the government could be perpetuating the brutality that these artists seek to challenge.

As they try to locate their work in the reality of the country's history, these artists have to dig deep into their memory. In an interview with Smith, Maseko refers to his memory of the Gukurahundi genocide: 
I was eight in 1983, but I remember a plane that flew low over our Bulawayo suburb and army loud-hailers screaming: 'You are surrounded.' Every family in Matabeleland has painful memories from this time and everyone knows people who disappeared. The soldiers organised mass executions and burned people in their homes. They forced others to watch and made them sing Shona songs. That's the subject of my painting, Babylon Songs (Maseko in Smith 1).

Here, Maseko draws attention to how memories of that painful part of the country's history are shared in the Matabeleland region. Importantly, he locates the family at the centre of these memories. According to him, people suffered collectively as families and neighbours and, as a result, when they remember that time, they do so as families and neighbours.

\section{Conclusion}

The banning of Cont Mhlanga's play and Owen Maseko's exhibition shows that, in many ways, the government of Zimbabwe is not prepared to confront the issue of Gukurahundi, and other brutalities it has unleashed on the people over the years. This should be read in the context of what Hall sees as the continuities and discontinuities of the colonial project, even at the postcolonial moment (Hall 224). The use of colonial laws such as POSA in outlawing, banning and stopping the performance and staging of artistic events seen as addressing an important national question, such as the Gukurahundi genocide, confirms the coloniality of Zimbabwe's postcolonial government, which continues to rely on the draconian and vampiristic colonial laws (Ndlovu-Gatsheni 11, Maldonaldo-Torres 243). With a specific reference to Matabeleland, it would seem, like the National Art Gallery in Bulawayo, which for some months was covered in newspapers so that people in the streets would not see the paintings, the region is still a crime site. More importantly, when Maseko gestures speak about the numerous shallow and undignified graves in the region, he draws our attention to how Matabeleland is living with a thick reality of "colonial presence" (Gregory 7). What can be seen as belonging to the colonial past is re-inscribed in the present in two important ways. First, the government, in its draconian treatment of the region, shows that it is a continuation of yesterday's colonial settler regimes. Second, the unresolved issues around Gukurahundi and the presence of graves echo the genocides associated with colonialism. This becomes 
more poignant when claims that the Gukurahundi is a genocide arising out of the unresolved postcolonial settlement of Zimbabwe's liberation struggle, pitting the West (Britain) against the east (Russia) in a geopolitical war fought in Matabeleland, are taken seriously (Scarnecchia 87).

The government's heavy-handed reaction also illustrates how space for expression is limited in Zimbabwe, in general, and in Matabeleland, in particular. It is the close down in space for self-expression that necessitates the rise of protest arts. South African poet Mafika Gwala, in one of his poems against the apartheid government, notes that as long as the government continues to abuse people, it would be right to disagree. From both Mhlanga and Maseko's conviction, it would seem that protest art is something that is felt strongly within one's conscience, something that keeps one awake such that they end up not fearing the government and its brutality. It is also important to note that in the case of the two artists, given their location and positioning in a specific region of Zimbabwe, a region seen as the hotbed of 'dissident' opposition politics, whatever they do as artists, especially when they produce work that questions the government, they are already seen as not only being hostile to the government but also hostile to another ethnic group. This comes out clearly in the case of Maseko, who is charged with "causing offence to persons of a particular race or religion”. Just as Mhlanga and Ndlovu-Gatsheni have pointed out, the official position of the government is to deny tribalism and ethnicity, hence the constitution evasively refers to 'race' and 'religion'. This is absurd, because Owen Maseko is black and the leadership of the country is black as well.

\section{References:}

Asher, Kiran. "Spivak and Rivera Cusicanqui on the Dilemmas of Representation in Postcolonial and Decolonial Feminisms." Feminist Studies, vol 43, issue 3, 2017: 512-24.

Bartlett, Lawrence. "Play about Political Corruption Causes Stir in Zimbabwe." AP News, 1 July 1987: https://apnews.com/77c8cf92575bccedfa9cf1fff7a10221. Accessed 15th of February 2019.

Bhambra, Gurminder, K. "Postcolonial and decolonial dialogues." Postcolonial Studies, vol 17, issue 2, 2014: 115-21.

Bleiker, Roland. Popular dissent, human agency and global politics. Cambridge University Press, 2000. 
Caplan, Gerald, L. "Barotseland: The secessionist challenge to Zambia." The Journal of Morden African Studies, vol 6, issue 3, 1968: 343-6o.

Catholic Commission for Justice and Peace (CCJP) and Legal Resources Foundation (LRF). Breaking the Silence, Building True Peace: Report on the Disturbances in Matabeleland and the Midlands, 1980-1989. CCJP \& LRF, 1997.

Chifunyise, Stephen. "Trends in Zimbabwean Theatre since 1980." Journal of Southern African Studies, vol 16, issue 2: 276-89.

Chikonzo, Kelvin. "From panic to reconciliation: Protest theatre and the state in Zimbabwe, 1999 - 2012.” Theatre Research International, vol 41, issue 3, 2016: $218-30$.

Cohen, Ted. "The Possibility of Art: Remarks on a Proposal by Dickie." The Philosophical Review, vol 82, issue 1, 1973: 69-82.

Dube, Caleb. “Amakhosi Theatre: AkoBulawayo.” The Drama Review, vol 36, issue 2, 1992: 44-47.

Gregory, Derek. The colonial present. Malden, MA: Blackwell Publishing, 2004.

Hall, Stuart. "When was 'the post-colonial'? Thinking at the Limit." The Postcolonial

Question: Common Skies, Divided Horizons, edited by Chambers, Ian and Curti,

Lidia. Routledge, 1996: 242-60.

Huyssen, Andreas. "Present Pasts.” Globalization. Edited by Arjun Appadurai. Duke University Press, 2001: 57-77.

Jonson, Lena. Art and protest in Putin's Russia. Routledge, 2015.

Maldonado-Torres, Nelson. "On Coloniality of Being: Contributions to the Development of a Concept.” Cultural Studies, vol 21, issues 2-3, 2007: 240-70. ---. “On the Coloniality of Human Rights.” Revista Crítica de Ciências Sociais, issue 114, 2017: 117-36.

Mhlanga, Brilliant. “Devolution - The 'ticklish' subject: The 'Northern problem' and the national question in Zimbabwe." Ubuntu, vol 1, issues 1 - 2, 2012: 206-31.

Mlotshwa, Khanyile. "Invisibility and hypervisibility" of 'Ndebele women' in Zimbabwe's media." Agenda, vol 32, issue, 2018: 87-99.

Mouffe, Chantal. The return of the political. Verso, 1993.

---. On the political. Routledge, 2005. 
Mpofu, Shepherd. “Art as Journalism in Zimbabwe: The case of Owen Maseko's banned Zimbabwean genocide exhibition.” Journalism Studies, vol 20, issue 1, 2019: 60-78.

Ndlovu-Gatsheni, and J. Sabelo. "Why decoloniality in the $21^{\text {st }}$ century?" The Thinker, issue 48, 2013: 10-15.

---. "The death of a subject with a capital ' $\mathrm{S}$ ' and the perils of belonging: $\mathrm{A}$ study of the construction of ethnocracy in Zimbabwe." Critical Arts: SouthNorth Cultural and Media Studies, vol 26, issue 4, 2012: 525-46.

Muzondidya, James, and Ndlovu-Gatsheni, Sabelo, J. “Echoing Silences': Ethnicity in post-colonial Zimbabwe, 1980-2007." African Journal on Conflict Resolution, vol7, issue 2, 2007: 275-97.

Mwando, Yamikani. "Political Theatre Rattles Ruling Party." IWPR, November 2007: https://iwpr.net/global-voices/political-theatre-rattles-ruling-party. Accessed on the 2nd of January 2019.

Ncube, Gibson, and Gugulethu Siziba. "(Re)membering the nation's 'forgotten”" past: Portrayals of Gukurahundi in Zimbabwean literature." The Journal of Commonwealth Literature, vol 52, issue 2, 2015: 231-47.

---. "Compelled to Perform in the 'Oppressor's' Language? Ndebele Performing Artists and Zimbabwe's Shona-Centric Habitus." Journal of Southern African Studies, vol 43, issue 4, 2017: 825-36.

Ramamurthy, Priti, and Ashwini Tambe. "Preface." Feminist Studies, Vol 43, issue 3, 2017: 503-11.

Reeds, Thomas Vernon. The art of protests: Culture and activism from the civil rights movement to the streets of Seattle. University of Minnesota Press, 2005 .

Scarnecchia, Timothy. "Rationalizing Gukurahundi: Cold War and South African Foreign Relations with Zimbabwe, 1981-1983.” Kronos, vol. 37, issue 1, 2011: 87-103.

Smith, David. "Letter from Africa: 'When you tell a joke in the street, that is political'”. The Guardian, $12^{\text {th }}$ of May 2009: https://www.theguardian.com/world/2009/may/12/david-smith-contmhlanga. Accessed on the 15th of February 2019. 
Smith Duval, Alex. "Zimbabwe artist defies Robert Mugabe." The Guardian, the $4^{\text {th }}$ of April 2010: https://www.theguardian.com/world/2010/apr/o4/zimbabweartist-arrest-mugabe-censorship. Accessed on the 15th of February 2019.

Sokwanele. "Art, censorship and the Gukurahundi: Freedom of expression in Zimbabwe”. Pambuzika News, 23 September 2010: https://www.pambazuka.org. Accessed on 2 January 2019.

Sulieman, Susan Rubin. Subversive Intent: Gender, Politics, and the Avant-Garde. Harvard University Press, 1990.

Wiseman, Mary and Lui Yuedi (eds.). Subversive strategies in contemporary Chinese art. Brill, 2011. 